\title{
Assessment of the level of knowledge regarding the intramuscular administration of medication among staff nurses
}

\author{
Ammu1, Sai Sailesh Kumar2*, Srilatha Bashetti ${ }^{3}$ \\ Little Flower Institute of Medical Sciences and Research, Kerala, India
}

\begin{abstract}
${ }^{1}$ Post Graduate student, Department of Hospital administration, Little Flower Institute of Medical Sciences and Research, Kerala, India. ${ }^{2}$ Assistant Professor, Department of Physiology, DM Wayanad Institute of Medical Sciences, Kerala, India.

${ }^{3}$ Tutor, Department of Biochemistry, Apollo Institute of Medical Sciences and Research, Hyderabad, India.
\end{abstract}

\begin{abstract}
Background and Objectives: Intramuscular injection is an everyday procedure which is not without its hazards. Although insuring bodies have pointed out that the lateral thigh is the least unsafe site for an IM injection. The commonly used sites in the adult are gluteal and deltoid muscle. The present study was undertaken to assess the level of knowledge related to intramuscular administration of medication among staff nurses.

Material and Methods: 30 samples were selected and descriptive research approach was used in the study. The level of study was assessed using self-administered questionnaire.

Results: $46.67 \%$ had inadequate knowledge, $40 \%$ had moderate knowledge regarding g the administration of IM injection. Efforts were also made to find the association between the level of knowledge and selected demographic variables. There is significant association between knowledge and educational status and years of clinical experience.

Conclusion: The present study assessed the knowledge of staff nurses regarding the administration of intramuscular (IM) medication and tries to find association between the level of knowledge and selected demographic variables. At the nd of the study, the investigators found that there is association between the level of knowledge, age, educational status and year of experience.
\end{abstract}

Keywords: Intramuscular Injection, Knowledge, Medication, Staff nurse

\section{INRODUCTION}

Intramuscular injection is an everyday procedure which is not without its hazards. Although the insuring bodies have pointed out that the lateral thigh is the least unsafe site for an IM injection commonly used sites in the adult are gluteal and deltoid muscle, the latter being both convenient for practitioners and acceptable to the recipient. Moreover, it is the only site recommended for administration in adult of a number of important vaccines including Hepatitis A and Hepatitis B.

An estimated 1-2\% of inpatients in the United States are harmed as a result of such errors 
(1). Administration errors are one of the most common types of medication errors. On the basis of the findings a number of UK observational studies in general hospitals, administration errors affect approximately 5\% of all administered doses (2). However, in a US study of 36 health care facilities the reported frequency was 19\% (3). Much of the research on administration errors has focused on general hospital and on errors involving intravenous drugs and infusions. Few studies of medication errors have been conducted in psychiatric settings and even fewer have concentrated on a retrospective review of records in a state psychiatric hospital, showed that administration errors were more frequent than prescribing, transcribing and dispensing errors combined (5). The above study shows that the major cause of errors in medication administration is the lack of adequate knowledge. The aim of the study reported was to assess the level of knowledge related to intramuscular administration of medication among staff nurses.

\section{MATERIAL AND METHODS Study Design}

The present study was a descriptive research approach conducted in medical wards of Medical College Hospital in Thrissur in the year 2016. Samples of 30 participants were included in the study. Prior permission was obtained from the nursing superintendent and ward in charge before conducting the study.

Those who meet the inclusion criteria will be selected using convenience sampling technique. A brief introduction about the self, research, and the self-administrating questionnaire was given to the staff. After 15 minutes the questionnaire was collected back, and the result were be kept confidential.

Inclusion criteria: All staff nurses working in medical ward during the period of data collection.
Exclusion criteria: Staff nurses who were not willing to participate in the study.

\section{Tools and Data Analysis}

The tool used for the study was questionnaire prepared by investigators under the guidance of experts. The questionnaire consists of two sections. First section consists of baseline characteristics of study subjects. Second section assesses the level of knowledge regarding the administration of IM injection among staff nurses. The data obtained was analyzed in view of objective of the study using descriptive and inferential statistics. The plan for data analysis was as follows:

- Frequencies and percentage of distribution was used to analyze the demographic data.

- Chi-square test was used to find the association between knowledge with selected demographic variables.

- The significant findings were represented in tables, figures and graphs.

\section{RESULTS}

\section{SECTION A: Analysis of Variables of Staff Nurses}

In the Table No.1 with referred to age, majority of staff nurses were in the age group of $21-25$ years, $20(66.7 \%)$, only $10(33.3 \%)$ were in the age group of 26-30 years. On the analysis of sex, majority of staff nurses were female, $22(73.3 \%)$ and only $8(26.7 \%)$ were males. On the analysis of educational status of staff nurses $18(60 \%)$ are having diploma and $12(40 \%)$ are having graduation. With referred to the clinical experience of staff nurses $11(36.7 \%)$ having experience of $12-24$ months, $9(30 \%)$ were having experience. 
Table I: Distribution of samples according to demographic variables

\begin{tabular}{|c|c|c|c|c|}
\hline $\begin{array}{l}\text { S. } \\
\text { No. }\end{array}$ & Demographic varia & & $\mathbf{F}$ & $\%$ \\
\hline \multirow[t]{6}{*}{1} & \multirow[t]{6}{*}{ Age in Years } & \multirow[b]{2}{*}{ a) Below 20} & \multirow[b]{2}{*}{0} & \multirow[b]{2}{*}{0} \\
\hline & & & & \\
\hline & & b) $21-25$ & 0 & 0 \\
\hline & & c) $26-30$ & 20 & 66.7 \\
\hline & & d) $31-35$ & 10 & 33.3 \\
\hline & & e) Above 36 & 0 & 0 \\
\hline \multirow[t]{2}{*}{2} & Sex & a)Male & 8 & \multirow{2}{*}{$\begin{array}{r}26.7 \\
73.3 \\
\end{array}$} \\
\hline & & b) Female & 22 & \\
\hline \multirow[t]{2}{*}{3} & Educational Status & \multirow{2}{*}{$\begin{array}{l}\text { a)Diploma } \\
\text { in Nursing } \\
\text { B)Graduate } \\
\text { in Nursing }\end{array}$} & 18 & \multirow{2}{*}{$\begin{array}{l}60 \\
40\end{array}$} \\
\hline & & & 12 & \\
\hline \multirow[t]{6}{*}{4} & \multicolumn{2}{|c|}{ Years of Clinical Experience } & & \multirow[b]{2}{*}{30} \\
\hline & & a) $<6$ Months & 9 & \\
\hline & & $\begin{array}{l}\text { b) } 7-12 \\
\text { Months }\end{array}$ & 7 & 23.3 \\
\hline & & \multirow{2}{*}{$\begin{array}{l}\text { c)13-24 } \\
\text { Months }\end{array}$} & & \multirow{2}{*}{36.7} \\
\hline & & & 11 & \\
\hline & & $\begin{array}{l}\text { d) }>24 \\
\text { Months }\end{array}$ & 3 & 10 \\
\hline \multirow[t]{5}{*}{5} & \multicolumn{2}{|c|}{$\begin{array}{l}\text { Frequency of Participation in } \\
\text { continuing education }\end{array}$} & & \\
\hline & & a) Once & 4 & 36.4 \\
\hline & & b) Twice & 2 & 18.2 \\
\hline & & c)Thrice & 1 & 9 \\
\hline & & $\begin{array}{lr}\text { d) } & \text { More } \\
\text { than } & 3 \\
\text { Times } & \\
\end{array}$ & 4 & 36.4 \\
\hline
\end{tabular}

of less than 6 months, 7(23.3\%) were having experience of $7-12$ months and $3(10 \%)$ were having experience of more than 24 months. On the analysis of frequency participation in continuing education program of nurses, $4(36.4 \%)$ attended once, $4(36.4)$ more than 3 times, 2(18.2) twice and $1(9 \%)$ attended thrice.

\section{SECTION B: Assessment of knowledge among staff nurses regarding intramuscular administration of medication}

Table II: Frequency and percentage distribution of knowledge of staff nurses regarding administration of IM

\begin{tabular}{|l|l|l|l|}
\hline $\begin{array}{l}\text { S. } \\
\text { No }\end{array}$ & Level of knowledge & Frequency & $\mathbf{\%}$ \\
\hline 1 & $\begin{array}{l}\text { Adequate knowledge } \\
(>75 \%)\end{array}$ & 4 & 13.3 \\
\hline 2 & $\begin{array}{l}\text { Moderately adequate }(51 \% \\
-75 \%)\end{array}$ & 12 & 40 \\
\hline 3 & $\begin{array}{l}\text { Inadequate knowledge } \\
(<50 \%)\end{array}$ & 14 & 46.67 \\
\hline
\end{tabular}

It is evident that majority of staff nurses (46.67\%) have inadequate knowledge, 4(13.3) have adequate knowledge. Remaining staff $12(40 \%)$ have moderately adequate knowledge.

\section{SECTION C: Association of selected demographic variables with knowledge of staffs regarding intramuscular administration of medication}

Table No. 3 shows that there is association between age and knowledge level. On the analysis of the sex, there is no association between sex and knowledge. With respect to educational status we found that there is significant association. As the educational status increases knowledge level increases. There is significant association between years of clinical experience and knowledge level. There is association between participation in continuing education program and knowledge.

\section{DISCUSSION}

Intramuscular (IM) injection is one of the most traditional and frequent procedures for the administration of medical and very much comes 


\section{Table III : Association of selected demographic variables with knowledge of staffs.}

\begin{tabular}{|c|c|c|c|c|c|c|}
\hline \multirow{2}{*}{ Demographic variables } & \multicolumn{4}{|c|}{ Knowledge level } & \multirow{2}{*}{$\mathbf{X}^{2}$} & \multirow{2}{*}{$d f$} \\
\hline & Adequate & $\begin{array}{l}\text { Moderately } \\
\text { adequate }\end{array}$ & Inadequate & $f$ & & \\
\hline \multicolumn{7}{|l|}{ Age in Years } \\
\hline a)Below 20 & 0 & 0 & 0 & 0 & \multirow{5}{*}{$18.095^{*}$} & \multirow{5}{*}{8} \\
\hline b) $21-25$ & 2 & 6 & 10 & 18 & & \\
\hline c) $26-30$ & 2 & 6 & 4 & 12 & & \\
\hline d) $31-35$ & 0 & 0 & 0 & 0 & & \\
\hline e) Above 36 & 0 & 0 & 0 & 0 & & \\
\hline \multicolumn{7}{|l|}{ Sex } \\
\hline a)Male & 1 & 5 & 2 & 8 & 8 & 2 \\
\hline b) Female & 3 & 7 & 12 & 22 & & \\
\hline \multicolumn{7}{|l|}{ Educational Status } \\
\hline a)Diploma in Nursing & 2 & 4 & 12 & 18 & $7.56^{*}$ & 2 \\
\hline $\begin{array}{l}\text { b)Graduate in } \\
\text { Nursing }\end{array}$ & 2 & 8 & 2 & 12 & & \\
\hline \multicolumn{7}{|l|}{$\begin{array}{ll}\text { Years of } & \text { Clinical } \\
\text { Experience }\end{array}$} \\
\hline a) $<6$ Months & 0 & 2 & 7 & 9 & & \\
\hline b) 7-12 Months & 1 & 1 & 5 & 7 & $18.74^{*}$ & 6 \\
\hline c) 13-24 Months & 1 & 8 & 2 & 11 & & \\
\hline d) $>24$ Months & 2 & 1 & 0 & 3 & & \\
\hline \multicolumn{7}{|l|}{$\begin{array}{ll}\begin{array}{l}\text { Participation } \\
\text { continuing education }\end{array} & \text { in }\end{array}$} \\
\hline a) Yes & 2 & 5 & 4 & 11 & 6.021 & 2 \\
\hline b) No & 2 & 7 & 10 & 19 & & \\
\hline \multicolumn{7}{|l|}{$\begin{array}{l}\text { Frequency of Participation } \\
\text { in continuing education }\end{array}$} \\
\hline a) Once & 1 & 2 & 1 & 4 & & \\
\hline b) Twice & 0 & 2 & 0 & 2 & $6.021^{*}$ & 6 \\
\hline c)Thrice & 1 & 0 & 0 & 1 & & \\
\hline d) More than 3 times & 2 & 1 & 1 & 4 & & \\
\hline \multicolumn{7}{|l|}{ * - significant association } \\
\hline $\mathrm{X}^{2}(8)=15.807$ & $X^{2}(2)=5.99$ & 2.59 & & & & \\
\hline
\end{tabular}

complex series of concerns relating to the

under nursing practices. IM injection is considered to be a basic skill, involves volume and type of inject ate to be administrated at the defined site (10). There 
are well established current guidelines for the best practice. Proper implementation of the techniques for example positioning of the injection, etc; will enable the nurse to perform efficiently and without causing damage to the nerve or artery during injecting the medicine [11-13]. The present study is taken up to know the knowledge and skills of the nurses working in LF as it ensures a better clinical approach in treating patients. In the present study we observed a varied response rate, regarding the knowledge of the staff nurses in the administration of intramuscular medication, $13.3 \%$ of staff nurses have adequate knowledge, $40 \%$ have moderate knowledge, and $46.7 \%$ have inadequate knowledge. The demographic variables were described in terms of age, sex, educational status and working experience in medical wards. It was found out that there is association between age, educational status, clinical experience and level of knowledge.

The outcome of the study stated that a young person with good educational status, with more clinical exposure had better level of knowledge in the intramuscular administration of medicines. On the other hand it was observed that there is no significant difference in the knowledge in respect to the gender.

From the present study it is learnt that the process of education has an information that is outdated which needs an update and gain knowledge about the revised new practices. The study also recommends written instructions for proper and efficient implementation of the procedures which in turn improves the quality of the patient care and uniformity in practicing the procedures. This may prevent adverse effects too.

\section{CONCLUSION}

The present study assessed the knowledge of staff nurses regarding the administration of intramuscular (IM) medication and tries to find association between the level of knowledge and selected demographic variables. At the end of study, the investigators found that there is association between the level of knowledge, age, educational status and year of clinical experience.

\section{LIMITATIONS}

The major limitation of the study was low sample size and study was conducted at a single center so results may not be generalized.

\section{ACKNOWLEDGEMENT}

We acknowledge Rev. Fr. Dr. George MD, Principal, Little Flower Institute of Medical Sciences and Research, for his support throughout the study.

\section{AUTHOR'S CONTRIBUTION}

All Authors contributed equally in designing the study, data collection and analysis and writing the article.

SOURCE OF SUPPORT: Self-funding

CONFLICT OF INTEREST: Nil

\section{REFERENCES}

1. Somayeh H and Ahmad RY. The practice of intensive care nurses using the closed suctioning system: An observational study. Iran J Nurs Midwifery Res 2015; 20(5): 619625.

2. Mohsen S, Ehsaneh RL, Azad B and Saeid A. Comparison of the effects of enteral feeding through the bolus and continuous methods on blood sugar and prealbumin levels in ICU inpatients. J Educ Health Promot 2015; 4: 95. 
3. Anna CV, Williams JS, Magdalena PK. Professional nurses' understanding of clinical judgement: A contextual inquiry. 2016;21: 280-293.

4. Susan C, Roxie B. Evaluation of the crosscultural health assessment as an interdisciplinary method of cultural competency education. Journal of Nursing Education and Pract 2014; 4(4): 58-73.

5. Jacob A, Rekha R \& Tharachand JSClinical Nursing Procedure; the art of nursing

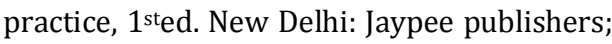
2007pp-65-80.

6. Ramtahal J, Ramlakhan S, Singh K. Sciatic nerve injury following IM Injection. The journal of neuroscience nurs (2006 );38(4):238-40.

7. Small SP. Preventing sciatic nerve injury from intramuscular injections: literature review. J Adv Nurs 2004; 47(3):287-96.

8. Bridget $M$. Are techniques used for intramuscular injection based on research evidence? Nursing Times 2008;104:48-51.

9. Zelman S. Notes on techniques of intramuscular injection. The avoidance of needless pain and morbidity. Am J Med Sci 1961; 241:563-74.

10. Malkin B. Are techniques used for intramuscular injection based on research evidence? Nurs Times 2008; 104:48-51.

11. Engstrom JL, Giglio NN, Takacs SM, Ellis MC, Cherwenka DI. Procedures usedy of to prepare and administer intramuscular injections: A study of infertility nurses. JOGNN 2000; 29:159-68.

12. Workman B. Safe injection techniques. Nurs Stand 1999; 13:47-53.

13. Dougherty L, Lister S. The Royal Marsden Hospital Manual of Clinical Nursing Procedures. 8th ed. West Sussex: WileyBlackwell; 2009 pp-7.

Correspondence to:
Sai Sailesh Kumar
Assistant Professor,
Department of Physiology,
DM Wayanad Institute of Medical Sciences,
Kerala, India
Email: Saisailesh.kumar@gmail.com

